\title{
Evaluation of an enzyme-linked immunosorbent assay to detect antibodies against Anaplasma marginale ${ }^{1}$
}

\author{
Cláudio R. Madruga² ${ }^{2}$, Ana Paula C. Marques², Cássia Rejane B. Leal ${ }^{2}$, Cristiano M.E. \\ Carvalho $^{2}$, Flábio R. Araújo ${ }^{3}$ and Raul H. Kessler ${ }^{2}$
}

\begin{abstract}
Madruga C.R., Marques A.P.C., Leal C.R.B., Carvalho C.M.E., Araújo F.R. \& Kessler R.H. 2000. Evaluation of an enzyme-linked immunosorbent assay to detect antibodies against Anaplasma marginale. Pesquisa Veterinária Brasileira 20(3):109-112. Embrapa Gado de Corte, Rodovia BR 262 Km 4, Cx. Postal 154, Campo Grande, MS 79002-970, Brazil.

A rapid indirect enzyme-linked immunosorbent assay (ELISA) was developed for measuring antibodies against Anaplasma marginale using a partially soluble antigen prepared from semipurified initial bodies from erythrocytes with $80.0 \%$ of rickettsiaemia. This technique utilized alkaline phosphatase and p-nitrophenyl phosphate as reaction indicators. The high sensitivity $(100.0 \%)$ was confirmed with sera from 100 calves experimentally-infected with $A$. marginale. All of these animals showed seroconversion before or at the same time of the first rickettsiaemia or even when it was not detected. Also the elevated specificity $(94.0 \%)$ was confirmed by the low percentage of cross-reactions with sera from animals experimentally-infected with Babesia bigemina and Babesia bovis (1.4 and 6.6\%, respectively). Performances of ELISA and indirect fluorescent antibody test (IFAT) with 324 sera from enzootically stable area did not show statistical difference $(\mathrm{P}>0.05)$, since the former showed $96.9 \%$ and the latter $97.2 \%$ of positive reactions. The advantage of this ELISA is a shorter execution time than others developed until now, allowing more samples to be analyzed.
\end{abstract}

INDEX TERMS: Anaplasma marginale, ELISA, serological tests, cattle.

RESUMO.- [Avaliação de uma prova de imunoadsorção enzimática para detecção de anticorpos contra Anaplasma marginale.] Um ensaio de imunoadsorção enzimática (ELISA) indireto, foi desenvolvido para detecção de anticorpos contra Anaplasma marginale, utilizando um antígeno parcialmente solúvel preparado a partir de corpúsculos iniciais semipurificados de eritrócitos com $80,0 \%$ de parasitemia. Esta técnica utilizou a fosfatase alcalina e o p-nitrofenil fosfato como indicadores de reação. A alta sensibilidade $(100,0 \%)$ foi comprovada com soros de 100 bezerros experimentalmente infectados $\operatorname{com} A$. marginale. Todos estes animais soroconverteram antes ou ao mesmo tempo que a primeira parasitemia foi detectada, ou mesmo quando não se obteve parasitemia. A elevada especificidade $(94,0 \%)$ foi confirmada pela baixa percentagem de reações cruzadas com soros de animais

\footnotetext{
${ }^{1}$ Accepted for publication on March 31, 2000.

${ }^{2}$ Embrapa Gado de Corte, Rodovia BR 262 Km 4, Cx. Postal 154, Campo Grande, MS 79002-970, Brasil.

${ }^{4}$ Universidade para o Desenvolvimento do Estado e da Região do Pantanal, Campo Grande, MS 79002-970, Brasil.
}

infectados experimentalmente com Babesia bigemina e Babesia bovis (1,4 e $6,6 \%$, respectivamente). Os desempenhos do ELISA e da imunofluorescência indireta (IFI) com 324 soros de uma área de estabilidade enzoótica não diferiram estatisticamente $(P>0,05)$, uma vez que o primeiro teste detectou $96,9 \%$ de reações positivas, enquanto o segundo, $97,2 \%$. A vantagem deste ELISA foi um menor tempo de execução do que outros desenvolvidos até o momento, permitindo a análise de um maior número de soros.

TERMOS DE INDEXAÇÃO: Anaplasma marginale, ELISA, testes sorológicos, bovino.

\section{INTRODUCTION}

Anaplasmosis is an infectious and transmissible disease of cattle and some wild ruminants, caused by the intraerythrocytic rickettsia Anaplasma marginale. This microorganism is widespread in tropical and subtropical areas of the world causing important economic losses, such as weight loss, reduced milk production, mortality and costs with treatment and prevention (Kessler et al. 1992).

In Brazil, as well as other Latin American countries, the economic impact is unknown but it is estimated to be high. 
In the United States the losses due to anaplasmosis were figured out around U\$ 300 millions per year (Palmer 1989).

Prevention may therefore be required in many circumstances and the best tool to make this decision is the prevalence data given by serological tests. Additionally, the serological tests are also important for evaluation of preventive measures employed to control anaplasmosis.

Many serologic techniques have been developed in the last decades, however the enzyme-linked immunosorbent assay (ELISA) that detect antibodies against various infectious diseases is the most advantageous, mainly because it is automated. ELISAs with higher sensitivity than the indirect fluorescent antibody technique (IFAT) (Goff \& Winward 1983), card agglutination (Rose et al. 1974) and complement fixation (Mahoney 1975) have been developed recently to detect antibodies against $A$. marginale (Barry et al. 1986, Nakamura et al. 1988, De Echaide et al. 1998, Reyna-Bello et al. 1998, Saliki et al. 1998, Molloy et al. 1999). However, these ELISAs are more time-consuming than the IFAT.

The present paper describes the development and standardization of an indirect ELISA, based on semi-purified antigen, for the detection of antibodies against $A$. marginale.

\section{MATERIALS AND METHODS}

The antigen source was calf blood with $80.0 \%$ rickettsaemia of Mato Grosso do Sul $A$. marginale isolate (Kessler et al. 1987). The infected erythrocytes were washed three times with phosphate buffer solution (10 mM Na $2 \mathrm{HPO}_{4} .2 \mathrm{H}_{2} \mathrm{O}, 6.4 \mathrm{mM} \mathrm{NaH}_{2} \mathrm{PO}_{4} .2 \mathrm{H}_{2} \mathrm{O}, 99 \mathrm{mM} \mathrm{NaCl}$ ), pH 7.2 (PBS), and stored at $-72^{\circ} \mathrm{C}$. During the antigen preparation, after thawing, the lysed erythrocytes were washed three times by centrifugation at $10,000 \times \mathrm{g}$ during 30 minutes at $4^{\circ} \mathrm{C}$ with PBS. After the last centrifugation, the intermediate layer was collected and lysed with a buffer solution containing $100 \mathrm{mM}$ Tris, $10 \mathrm{mM}$ EDTA, $0.2 \mathrm{mM} \mathrm{N}$-a-p-tosyl-L-lysil chloromethyl ketone, $2.0 \mathrm{mM}$ phenylmethyl sulfonylfluoride and $2.0 \%$ Tergitol NP-40 (v/v), and by ultrasonic disruption $(100 \mathrm{~W})$ for 10 minutes. The material was centrifuged for 60 minutes at $14,000 \mathrm{x}$ g at $4^{\circ} \mathrm{C}$ and the supernatant was harvested and used as antigen. The total protein concentration of the antigen, measured by bicinchoninic acid method was 16.9 $\mathrm{mg} / \mathrm{ml}$.

The following procedure was the choice after a series of experiments based on the largest optical density difference between positive and negative control sera. The antigen was diluted 1:5,000 in carbonate/bicarbonate buffer, pH $9.0\left(200 \mathrm{mM} \mathrm{Na} \mathrm{CO}_{3}, 199 \mathrm{mM}\right.$ $\mathrm{NaHCO}_{3}$ ) and $100 \mathrm{ml} /$ well were added to 96 well plates (Costar). The adsorption time of the antigen was four hours at $4^{0} \mathrm{C}$. Subsequently, the plates were washed five times with PBS containing $0.1 \%$ Tween 20 (PBST). One hundred microliters of bovine serum, diluted 1:1,000 in PBST, were added to each well and incubated for 45 minutes at $37^{0} \mathrm{C}$. After washing as described above, $50 \mu \mathrm{l}$ of rabbit anti-bovine IgG alkaline phosphatase conjugate (Sigma), diluted 1:24,000 in PBST, were added to each well and the plates were incubated for 30 minutes. After washing the plates 10 times with PBST, $50 \mu \mathrm{l}$ of the substrate $1.0 \mathrm{mM}$ p-nitrophenyl phosphate were added to each well. The reaction was stopped 15 minutes later by adding $100 \mu \mathrm{l}$ of 0.2 $\mathrm{M} \mathrm{NaOH}$ to each well and results were obtained in a microplate reader with a $405 \eta \mathrm{m}$ wavelenght.

A plate with negative and positive sera was setup as a standard and it was used for adjustment of the test plate each time the ELISA was performed. The same three positive sera and three negative sera were used as controls in the test plates and were used for adjustment of the optical density (OD) using the following formula: $\mathrm{F}=\mathrm{PO}$-N0/Pt-Nt, where $\mathrm{F}$ is the adjustment factor, N0 is the mean OD for the negative sera and $\mathrm{PO}$ is the mean $\mathrm{OD}$ for the positive sera in the standard plate. $\mathrm{Nt}$ and $\mathrm{Pt}$ are the mean ODs for the same negative and positive sera in the test plate. The adjusted OD (AOD) for the test serum was obtained by $\mathrm{AOD}=\mathrm{F}(\mathrm{St}-\mathrm{Nt})+\mathrm{N} 0$, where $\mathrm{St}$ is the mean OD for the serum tested.

The cut-off was determined as the OD mean of 66 cattle sera from tick-free area plus two standard deviations. The validity of the test (sensitivity, specificity, positive and negative predictive values and precision) was determined according to Coggon et al. (1993).

The ELISA sensitivity was determined with 100 sera from cattle infected with $A$. marginale. The ELISA specificity was determined with 100 sera kept in a bank of the Beef Cattle National Research Center (Campo Grande, MS, Brasil), obtained from Anaplasma-free calves, held in an isolation area of this Center. Blood smears from these animals were analyzed for $A$. marginale. Also serum samples were analyzed by IFAT for $A$. marginale antibodies. Only calves negative in both tests were included in this study.

The A. marginale ELISA was also evaluated with 140 sera from 10 intact 6-8 months-old Nellore calves free from Babesia sp. and Anaplasma sp. infection and then experimentally-inoculated with $10^{10}$ $B$. bigemina infected erythrocytes. Also, 30 sera from six calves experimentally-inoculated four times with $10^{7} \mathrm{~B}$. bovis infected erythrocytes were tested.

Sera of 324 cattle from an enzootically stable region (Bahia State, Brazil) were analyzed by ELISA and IFAT for detection of antibodies against $A$. marginale. The IFAT was performed according to Goff \& Winward (1983). The comparison between the prevalences of positive sera detected by both tests were carried out by qui-square test, with a $95.0 \%$ interval of confidence.

\section{RESULTS AND DISCUSSION}

The cut-off of the 66 cattle sera from tick-free area was 0.085 . The results showed that all sera from $A$. marginale-infected cattle analyzed were positive for antibodies against this rickettsia, corresponding to a sensitivity of $100.0 \%$. Six out of the 100 sera from Anaplasma-free calves showed false-positive reactions, corresponding to a specificity of $94.0 \%$. Positive and negative predictive values were, respectively, $94.3 \%$ and $100.0 \%$ and precision of the test was $97.0 \%$ (Table 1).

With regards to the cross-reaction analyzes, from the 30

Table 1. Results of the ELISA with sera from calves experimentallyinoculated with Anaplasma marginale or free from infection with this rickettsia and analysis of validity of the test ${ }^{\mathrm{a}}$

\begin{tabular}{cccc}
\hline \multicolumn{4}{c}{ Infection status of the calves } \\
\hline ELISA & Positive & Negative & Total \\
Positive & $100(\mathrm{a})$ & $6(\mathrm{~b})$ & $106(\mathrm{a}+\mathrm{b})$ \\
Negative & $0(\mathrm{c})$ & $94(\mathrm{~d})$ & $94(\mathrm{c}+\mathrm{d})$ \\
Total & $100(\mathrm{a}+\mathrm{c})$ & $100(\mathrm{~b}+\mathrm{d})$ & $200(\mathrm{a}+\mathrm{b}+\mathrm{c}+\mathrm{d})$ \\
\hline
\end{tabular}

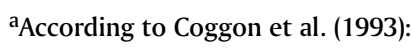

Sensitivity: $\mathrm{a} /(\mathrm{a}+\mathrm{c}) \times 100=100 / 100 \times 100=100.0 \%$

Specificity: $d /(b+d) \times 100=94 / 100 \times 100=94.0$

Positive predictive value: $\mathrm{a} /(\mathrm{a}+\mathrm{b})$ x $100=100 / 106$ × $100=94.3 \%$

Negative predictive value: $d /(c+d) \times 100=94 / 94 \times 100=100.0 \%$

Precision $(a+d) /(a+b+c+d) \times 100=194 / 200 \times 100=97.0 \%$ 
anti-sera to $B$. bovis tested against $A$. marginale antigen, $2(6.7 \%)$ showed positive reactions. Cross-reactions with $B$. bigemina were found in 2 out of the 140 anti-sera tested on Anaplasma ELISA (Table 2). In both cases, the cross-reactions occurred in the acute phase of the infection (data not shown).

Table 2. Cross-reactions analyzes with sera from calves experimentally-infected with Babesia spp. on Anaplasma ELISA

\begin{tabular}{lcc}
\hline Anti-sera to & $\mathrm{N}^{\circ}$ of sera tested & $\mathrm{N}^{\circ}$ of cross-reactions (\%) \\
\hline Babesia bovis & 30 & $2(6.7)$ \\
Babesia bigemina & 140 & $2(1.4)$
\end{tabular}

With regards to the comparative performance of the ELISA and IFAT (Table 3), the differences between the prevalences detected by both tests $(96.9 \%$ and $97.2 \%$, respectively) were not statistically significant $(P>0.05)$. From 324 sera analyzed, 308 were ELISA+/IFAT + and 3 were ELISA-/IFAT-, corresponding to an agreement of $96.0 \%$ between the results shown by both tests.

Table 3. Comparison of the results obtained with ELISA and IFAT in detecting antibodies against Anaplasma marginale with sera of calves from an enzootically-stable area

\begin{tabular}{cccc}
\hline \multicolumn{4}{c}{ ELISA } \\
\hline IFAT & Positive & Negative & Total \\
\hline Positive & 308 & 7 & 315 \\
Negative & 6 & 3 & 9 \\
Total & 314 & 10 & 324
\end{tabular}

The data showed that the ELISA evaluated showed a high sensitivity, comparable to other ELISAs described (Montenegro-James et al. 1990, Nielsen et al. 1996, Molloy et al. 1999). Nevertheless, the present ELISA had the advantage to be performed in shorter period of time than others developed until the present time (Duzgun et al. 1988, Shkap et al. 1990, Knowles et al. 1995, Nielsen et al. 1996, ReynaBello et al. 1998, Saliki et al. 1998, Molloy et al. 1999).

The specificity of this ELISA was also elevated and was comparable with other ELISAs based on crude antigens (Duzgun et al. 1988, Shkap et. al. 1990) and not much lower than the ELISAs with recombinant protein (De Echaide et al. 1998, Molloy et al. 1999).

The reduced number of cross-reactions with animals experimentally-inoculated with $B$. bigemina and $B$. bovis endorses the high specificity of this serological test. Although this ELISA antigen contains erythrocyte stroma contamination, probably it was not a relevant factor of false-positive reactions.

The comparison between ELISA and IFAT showed that the performances of both tests in detecting antibodies against $A$. marginale in an enzootically stable area did not differ statistically $(\mathrm{P}>0.05)$ and showed a concordance degree very high. Likely, the antigen prepared from blood with high rickettsaemia, without antibodies against Anaplasma, and before accentuated packed cell volume decrease had been occurred, were important factors for the antigen quality. Furthermore, the utilization of Tergitol NP-40 in the antigen preparation not only may have contributed for the high sensitivity, but may have increased the specificity, what is in agreement with Nakamura et al. (1988).

Although the IFAT is one of the most commonly used test, ELISA has some advantages over it, since results can be obtained directly through a microplate reader, making possible to evaluate a larger number of serum samples and avoiding problems with doubtful interpretations, common in weak fluorescent reactions.

\section{REFERENCES}

Barry D.N., Parker R.J., De Vos A.J., Dunster P. \& Rodwell B.J. 1986. A microplate enzyme-linked immunosorbent assay for measuring antibody to Anaplasma marginale in cattle serum. Aust. Vet. J. 63:76-79.

Coggon T., Rose G. \& Barker D.J. 1993. Measurement, error and bias, p. 2025. In: Coggon T., Rose G. \& Barker D.J. (ed.) Epidemiology for the Uninitiated. 3rd ed. BMJ Publishing Group, London.

De Echaide S.T., Knowles D., McGuire T.C., Palmer G.H., Suarez C.E. \& McElwain T.F. 1998. Detection of cattle naturally infected with Anaplasma marginale in a region of endemicity by nested PCR and a competitive enzyme immunosorbent assay using a recombinant major surface protein 5. J. Clin. Microbiol. 36:777-782.

Duzgun A., Schuntner C.A., Wright I.G., Leatch G. \& Waltisbuhl D.J. 1988. A sensitive ELISA technique for the diagnosis of Anaplasma marginale infections. Vet. Parasitol. 29:1-7.

Goff W.L. \& Winward L.D. 1983. A modified indirect fluorescent test for the diagnosis of Anaplasma marginale infection in cattle: comparison with complement fixation and card agglutination. Proc. Int. Symp. World Assoc. Vet. Lab. Diag. 3:665-672.

Kessler R.H., Schenk M.A.M., Madruga C.R., Sacco A.M.S. \& Miguita M. 1992. Tristeza parasitária dos bovinos (TPB), p.1-30. In: Furlong J. \& Charles T.P. (ed.) Doenças Parasitárias dos Bovinos de Leite. EMBRAPA-CNPGL, Coronel Pacheco, MG.

Kessler R.H., Madruga C.R., Jesus E.F. \& Semprebom D.V. 1987. Isolamento de cepas puras de Babesia bovis, Babesia bigemina e Anaplasma marginale em área enzoótica. Pesq. Agropec. Bras. 22:7-10.

Knowles D.P., Perryman L.E., McElwain T.F., Kappmeyer L.S., Stiller D., Palmer G.H., Visser E.S., Hennager S.G., Davis W.C. \& McGuire T.C. 1995. Conserved recombinant antigens of Anaplasma marginale and Babesia equi for serologic diagnosis. Vet. Parasitol. 57:93-96.

Mahoney D.F. 1975. The diagnosis of babesiosis in Australia, p.49-62. In: Workshop on Hemoparasites (Anaplasmosis and Babesiosis). CIAT, Cali.

Molloy J.B., Bowles P.M., Knowles D.P., McElwain T.F., Bock R.E., Kingston T.G., Blight G.W. \& Dalgliesh R.J. 1999. Comparison of a competitive inhibition ELISA and the card agglutination test for detection of antibodies to Anaplasma marginale and Anaplasma centrale in cattle. Aust. Vet. J. 77:245249.

Montenegro-James S., Guillen A.T., Ma S.J., Tapang P., Abdel-Gawad A., Toro M. \& Ristic M. 1990. Use of the dot enzyme-linked immunosorbent assay with isolated Anaplasma marginale initial bodies for serodiagnosis of anaplasmosis in cattle. Am. J. Vet. Res. 51:1518-1521.

Nakamura Y., Shimizu S., Minami T. \& Ito S. 1988. Enzyme-linked immunosorbent assay using solubilised antigen for detection of antibodies to Anaplasma marginale. Trop. Anim. Hlth Prod. 20:259-266.

Nielsen K., Smith P., Gall D., de Eshaide ST, Wagner G \& Dajer A. 1996. Development and validation of an indirect enzyme immunoassay for detection of antibody to Anaplasma marginale in bovine sera. Vet. Parasitol. 67:133-142.

Palmer G.H. 1989. Anaplasma vaccines, p.1-29. In: Wright I.G. (ed.) Veterinary Protozoan and Hemoparasite Vaccines. CRC Press, Boca Raton.

Reyna-Bello A., Cloeckaert A., Vizcaino N., Gonzatti M.I., Aso P.M., Dubray G. \& Zygmunt M.S. 1998. Evaluation of an enzyme-linked immunosorbent 
assay using recombinant major surface protein 5 for serological diagnosis of bovine anaplasmosis in Venezuela. Clin. Diagn. Lab. Immunol. 5:259262.

Rose J.E., Amerault T.E. \& Roby T.O. 1974. Roles of conglutinin, complement and antiboddy size in the card agglutination test for bovine anaplasmosis. Am. J. Vet. Res. 35:1147-1151.
Saliki J.T., Blouin E.F., Rodgers S.J. \& Kocan K.M. 1998. Use of tick cell culturederived Anaplasma marginale antigen in a competitive ELISA for serodiagnosis of anaplasmosis. Ann. New York Acad. Sci. 849:273-281.

Shkap V., Bin H., Ungar-Waron H. \& Pipano E. 1990. An enzyme-linked immunosorbent assay (ELISA) for the detection of antibodies to Anaplasma centrale and Anaplasma marginale. Vet. Microbiol. 25:45-53. 